\title{
Impact of Shoot and Cluster Thinning on Yield, Fruit Composition, and Wine Quality of Corot noir
}

\author{
Qun Sun, ${ }^{1}$ Gavin L. Sacks, ${ }^{2}$ Steven D. Lerch, ${ }^{3}$ and Justine E. Vanden Heuvel ${ }^{4,5 *}$
}

\begin{abstract}
Cluster thinning (CL), shoot thinning (ST), and a combination of the two practices (ST+CL) were applied to vigorous Corot noir (hybrid sp.) winegrapes grown at a commercial vineyard in the Finger Lakes region of New York State. Yield was reduced by CL (by up to $4.8 \mathrm{~kg} / \mathrm{vine}$ ) but not ST in 2008, and by ST (by up to $2.0 \mathrm{~kg} / \mathrm{vine}$ ) and not CL in 2009; however, high pruning weights (up to $4.5 \mathrm{~kg} / \mathrm{vine}$ in 2008) and low crop-load ratios (ranging from 2.3 to 7.1) indicated that vines in the study were undercropped regardless of treatment. CL increased soluble solids by up to 2.5 Brix in 2008 and by up to 0.8 Brix in the ST+CL treatment in 2009, while ST increased soluble solids in 2009 by 0.8 Brix. The treatments had variable impacts on wine anthocyanin, berry skin tannin, berry seed tannin, and wine tannin depending on year. Wine tannin (42 to $64 \mathrm{mg} / \mathrm{L})$ and tannin extractability (5 to $6 \%)$ were both very low compared to values typically observed in red wines produced from $V$. vinifera. Using a two-alternative forced choice test, panelists reported ST $+\mathrm{CL}$ wines were fruitier than the control and ST wines and that ST wines were less fruity than the control in both years. An economic analysis indicated that in order for growers/wineries to maintain their economic welfare, bottle prices would have to increase by $\$ 0.02$ to $\$ 0.41$ depending on the practice and year to compensate for additional labor costs and lost yield in implementing these crop-load management practices.
\end{abstract}

Key words: crop-load management, economic sustainability, cost of production

Corot noir is a complex interspecific red hybrid winegrape released by Cornell University in 2006. It ripens mid- to late season, is appropriate for either blending or the production of varietal wines, and is moderately winter hardy (LT50 = $-23^{\circ} \mathrm{C}$ ) with moderate resistance to fungal diseases (Reisch et al. 2006). Observations made at Geneva, NY, from 1996 to 2005 indicated that the vine size of Corot noir was smaller than GR7 (average pruning weight of $1.4 \mathrm{~kg} / \mathrm{vine}$ compared to 2.1 for GR7), and observations made during roughly the same period at three locations in Indiana also suggest a small vine size (average pruning weight of $0.6 \mathrm{~kg} / \mathrm{vine}$ from 2000 to 2005 compared to $1.0 \mathrm{~kg}$ /vine for Marechal Foch at Vincennes, IN) (Reisch et al. 2006). However, anecdotal observations by commercial growers in the Finger Lakes region of New York have characterized Corot noir as perhaps the most vigorous French-American hybrid grown in the region, exhibiting high fruit yield, vigorous canopy growth, and low cluster light exposure.

\footnotetext{
${ }^{1}$ Graduate Student, ${ }^{2}$ Assistant Professor, Department of Food Science, and ${ }^{3}$ Research Support Specialist, ${ }^{4}$ Assistant Professor, Department of Horticulture, NYSAES, Cornell University, Geneva, NY 14456; and ${ }^{5}$ Department of Horticulture, Cornell University, Ithaca, NY 14850.

*Corresponding author (email: jev32@cornell.edu)

Acknowledgments: The project was funded by the New York Farm Viability Institute and the New York Wine and Grape Foundation (Total Quality Focus and Sustainability program).

The authors thank Swedish Hill Winery for hosting the experiment, Luann Preston-Wilsey and Pamela Raes for their technical assistance, John Barnard for advice on statistical analyses, Tim Martinson and Bill Wilsey for field assistance, and Trent Preszler for contributing expertise to the economic analysis. Manuscript submitted Mar 2011, revised Jun 2011, Sept 2011, accepted Sept 2011 Copyright (C) 2012 by the American Society for Enology and Viticulture. All rights reserved.
}

doi: 10.5344/ajev.2011.11029
Both shoot thinning (ST) and cluster thinning (CL) are recommended viticultural practices for many French-American hybrids because of their propensity to overcrop (Cahoon and Nonnecke 1982). ST has been shown to improve fruit quality of several French-American hybrids such as Seyval blanc (Reynolds et al. 1986), Aurore, Chancellor and Villard noir (Morris et al. 2004), and Marechal Foch (Sun et al. 2011). $\mathrm{CL}$ is commonly used as a corrective viticultural measure to allow the remaining fruit to reach a higher level of maturity by improving the leaf area to fruit ratio and has been demonstrated to improve various quality metrics in Vidal blanc (Wolpert et al. 1983, Howell et al. 1987), Chambourcin (Prajitna et al. 2007), and De Chaunac (Fisher et al. 1977, Looney 1981). While these studies indicate that canopy management practices can often result in improved fruit quality, in a commercial vineyard operation the additional costs associated with implementing CL and ST would need to be carefully considered together with the economic benefits of potential enhancements to fruit quality (Preszler et al. 2010). Corot noir is a relatively recent release, so there is little information available on best management practices for this cultivar. The objective of this study was to investigate the impact of ST and CL treatments on yield components, fruit composition, and wine quality of Corot noir.

\section{Materials and Methods}

Vineyard site and experimental design. Five-year-old own-rooted Corot noir vines located at a commercial winery on the west side of Cayuga Lake in Romulus, NY, were subjected to canopy and crop-load management treatments in 2008 and 2009. Soil in the block was a Darien-Danley Cazenovia silt loam (USDA-NRCS soil maps). Vines were spaced at 2.4 x $2.7 \mathrm{~m}$ (vine $\mathrm{x}$ row) in north-south oriented rows and trained to a high-wire cordon system with three vines per panel. 
Because the northern end of the vineyard was lower in vigor than the southern end, mulch was applied in 2009 to the two replications of the experiment located in the northern end of the planting. Drip irrigation was installed throughout the vineyard. Standard pest control practices for the region were used.

The experimental design was a 2 x 2 factorial with ST and CL; treatments consisted of two ST treatments (no ST and ST) combined with two CL treatments (no CL and CL) in a randomized complete block design with four replications. Each experimental unit consisted of 13 contiguous panels of vines, with two panels in each plot randomly selected at the beginning of the experiment for data collection. For the ST treatment in 2008, 15 primary shoots were retained per meter and all secondary, tertiary, and noncount shoots were removed (Mullins et al. 1992, Pool et al. 1978). In 2009, 30\% of primary shoots were damaged by a May frost prior to application of the ST treatment, resulting in some secondary shoots being maintained along with primary shoots at a density of 15 shoots per meter. ST was conducted when shoots reached approximately 5 to $15 \mathrm{~cm}$ in length in May. No ST was applied in the control plots. For the CL treatment, the distal cluster was removed from each shoot that had more than two clusters. CL was conducted when berries reached approximately pea-size (approximate Eichhorn-Lorenz stage 31), and no CL was applied in the control plots.

Yield components. Vines were individually harvested by hand on 21 Oct 2008 and 16 Oct 2009 immediately before commercial harvest. Yield per vine was quantified using a hanging scale (Salter Weigh-Tronix, Fairmont, MN), and cluster number per vine was counted. Cluster weights were calculated by dividing yield by cluster number on a per vine basis. A random sample of 20 clusters per data panel was collected at harvest and stored at $-40^{\circ} \mathrm{C}$ until analysis. Subsamples of 100 berries were weighed to determine mean berry weight. Berry number per cluster was calculated by dividing cluster weight by berry weight.

In January 2010, vines were pruned according to grower specifications and pruning weights were collected on a per vine basis in each data panel. Crop load for 2009 was calculated by dividing yield by pruning weight on a per vine basis. In January 2009, the grower pruned all vines in the planting prior to data collection. As a result, pruning weights were estimated immediately following commercial pruning on a per panel basis by raking and weighing the vine prunings which were lying on the vineyard floor between the posts defining the data collection panels. Crop load for 2008 was calculated by dividing yield by pruning weight on a per panel basis.

Canopy characterization. Enhanced point quadrat analysis (EPQA) (Meyers and Vanden Heuvel 2008) was used to characterize canopy light environment at approximately veraison in both years of the study. A sharpened thin metal rod was inserted into the canopy at $10 \mathrm{~cm}$ intervals and sequential contacts of leaves, clusters, and canopy gaps from one side to the other were recorded. Photon flux measurement was performed according to a previously described method (Meyers and Vanden Heuvel 2008) using a Decagon ceptometer (Decagon, Pullman, WA). Canopy parameters were ana- lyzed by EPQA and CEM Tools (version 1.6) (available free of charge from J. Meyers,jmm533@cornell.edu). Occlusion layer number (OLN; number of shade producing contacts per insertion), cluster exposure layer (CEL; number of shading layers between cluster and nearest canopy boundary), cluster exposure flux availability (CEFA; percentage of abovecanopy photon flux that reaches clusters), and leaf exposure flux availability (LEFA; percentage of above-canopy photon flux that reaches leaves) were calculated.

Berry and wine composition. A 100 berry sample was collected randomly in duplicate from each sample that was frozen as described above. The frozen berries were thawed at room temperature before analysis. The berries were juiced by a blender and the slurry was pressed through cheese cloth. Brix was measured using an Abbé temperature-compensated refractometer (ATAGO, Bellevue, WA). Berry and wine $\mathrm{pH}$ were measured using an Orion 3-Star pH meter (Thermo Fisher Scientific, Waltham, MA), and titratable acidity (TA) was determined on a $10 \mathrm{~mL}$ sample by autotitration (Digital Buret, BrandTech Scientific, Essex, CT) using 0.1 M NaOH to an endpoint of $\mathrm{pH} 8.2$. Wine alcohol content was measured by ebulliometer (DuJardin-Salleron, Arcueil, France). Wine lactate, acetate, glucose, and fructose were quantified by Fourier transform-IR (WineScan FT120 Basic, FOSS, Eden Prairie, MN) to confirm that fermentations went to dryness and spoilage did not occur (data not shown). Wine free $\mathrm{SO}_{2}$ was measured by the Ripper method (data not shown). Berry and wine anthocyanins and tannins were determined by the Adams-Harbertson assay (Harbertson et al. 2003). Tannin extractability was calculated by the following equation:

tannin extraction $=$

wine tannin $\left(m g \cdot L^{-1}\right) \times$ wine volume $(L) \times 100 \%$

$\left[\frac{\text { skin tannin }\left(\mathrm{mg}^{\prime} \cdot \text { berry }^{-1}\right)+\text { seed tannin }\left(\mathrm{mg}^{-} \text {berry }^{-1}\right)}{\text { berry weight }\left(\mathrm{g} \cdot \text { berry }^{-1}\right)}\right\rfloor \times \frac{\text { fruit mass }(\mathrm{kg})}{1000}$

The ratio of the wine volume (L) to the fruit mass represents yield $(\mathrm{kg})$. A mean yield value of 0.65 was used for all treatments.

Winemaking. Wines were made in duplicate after combining all four field replicates for each treatment and then subdividing the fruit into duplicate lots. Fruit was destemmed, crushed, and treated with $50 \mathrm{mg} \mathrm{L}^{-1}$ sulfur dioxide added as potassium metabisulfite. Diammonium hydrogen phosphate (DAP) (Presque Isle Wine Cellars, PA) was added at a rate of $1 \mathrm{~g} \mathrm{~kg}^{-1}$, Fermaid K (Lallemand, Rexdale, ON, Canada) at 0.1 $\mathrm{g} \mathrm{L}^{-1}$, and Goferm (Lallemand) at $0.15 \mathrm{~g} \mathrm{~L}^{-1}$. Skin fermentation was performed in temperature-controlled $114 \mathrm{~L}$ stainlesssteel fermentors. Cap management was performed twice per day by manual punch-downs. The must was brought to $20^{\circ} \mathrm{C}$ and inoculated with ICV-GRE (Lallemand) to $0.27 \mathrm{~g} \mathrm{~L}^{-1}$. The temperature profile of the fermentations was computer controlled. During the first three days of fermentation, the must was warmed slowly from $20^{\circ} \mathrm{C}$ to a maximum between 30 and $35^{\circ} \mathrm{C}$. For the remainder of the alcoholic fermentation, the temperature was kept between 20 and $30^{\circ} \mathrm{C}$. Fermentations were stopped when residual sugar was $<0.5 \%$ by Clinitest tablets 
(Bayer, Etobicoke, ON, Canada). At the end of fermentation, wines were pressed, racked into glass carboys, and inoculated with Alpha (Lallemand) to start malolactic fermentation (MLF). Upon completion of MLF, potassium metabisulfite was added to maintain $40 \mathrm{mg} \mathrm{L}^{-1}$ free sulfur dioxide. Wines were cold stabilized at $2^{\circ} \mathrm{C}$. Titratable acidity was adjusted to 6.5 $\mathrm{g} \mathrm{L}^{-1}$ by addition of tartaric acid or potassium carbonate after cold stabilization. The wines were screened for faults by an expert panel prior to bottling. Bottling and screwcapping were performed manually.

Sensory test. Wines from 2008 and 2009 were evaluated after bottle aging and compared in November 2010 for all four treatments by two-alternative-forced choice (2-AFC) test (Lawless and Heymann 2010). Sixteen panelists with wine evaluation experience were recruited for the test. A pair of coded samples for comparison was presented to panelists. The panelists were asked to select the sample with the stronger fruitiness. Wines from each treatment were compared to one another. Each comparison was duplicated. One wine sample was randomly selected for sensory evaluation from duplicate wines. Presensory testing was performed to ensure the replicates did not differ.

Economic analysis. A simple economic analysis was performed to determine the additional price per tonne and cost per $750 \mathrm{~mL}$ bottle of wine a producer would need to receive in order for them to maintain the same economic welfare (i.e., revenue/ha or revenue/case) if the ST or CL practices were adopted compared to if they were not. Additional production cost per hectare for each treatment was determined according to White (2008), and then additional production cost/tonne was calculated by dividing the additional production cost/ha by the yield (tonne/ha). Expected revenue/ha was calculated by multiplying yield (tonne/ha) by the average industry price for Corot noir (Walter-Peterson 2008, 2009). The grower preferred price/tonne to maintain economic welfare was calculated by dividing the expected revenue/ha for the control treatment $(\$ 13,279$ in $2008, \$ 4,844$ in 2009$)$ by the yield (tonne/ha) and then adding the additional production cost/tonne. Additional cost per $750 \mathrm{~mL}$ bottle of wine was determined by subtracting the average price per tonne from the grower preferred price/tonne for each treatment, and then dividing by 655.2 (the number of $750 \mathrm{~mL}$ bottles that can be produced from one metric tonne of grapes).

Statistical analysis. Mixed model ANOVAs and LSDs were generated using JMP (version 8.0; SAS Institute, Cary, $\mathrm{NC})$, with type I error rate $(\propto)$ set at 0.05 for all statistical tests. Statistical analysis of the 2-AFC test was performed by a two-tailed chi-squared test (JMP 8.0).

\section{Results and Discussion}

Yield components and vine growth. In 2008, CL decreased yield through a decrease in cluster number per vine compared to the control (Table 1). However, individual cluster weight was increased by both ST and CL. Cropload ratio was decreased by both ST and CL. The ST by CL interaction was significant and had an additive effect for cluster number per vine and berry weight.

In 2009, CL resulted in fewer clusters per vine compared to the control, but the increased average cluster weight resulted in CL having no impact on yield per vine, similar to results reported for Seyval blanc (Reynolds et al. 1986). ST significantly reduced yield per vine in 2009 through a decrease in cluster number (Table 1). Crop-load ratio was reduced by ST, while CL surprisingly had no impact on crop load at harvest.

Table 1 Impact of shoot thinning and cluster thinning on yield components and vegetative growth of Corot noir.

\begin{tabular}{|c|c|c|c|c|c|c|c|}
\hline Treatment $^{\mathrm{a}}$ & $\begin{array}{c}\text { Yield/ } \\
\text { vine (kg) }\end{array}$ & $\begin{array}{c}\text { Clusters/ } \\
\text { vine }\end{array}$ & $\begin{array}{c}\text { Cluster wt } \\
(\mathbf{k g})\end{array}$ & $\begin{array}{l}\text { Berries/ } \\
\text { cluster }\end{array}$ & $\begin{array}{c}\text { Berry wt } \\
(\mathrm{g})\end{array}$ & $\begin{array}{c}\text { Pruning wt } \\
(\mathbf{k g})\end{array}$ & $\begin{array}{l}\text { Crop load } \\
\text { (kg yield/kg } \\
\text { pruning wt) }\end{array}$ \\
\hline \multicolumn{8}{|l|}{2008} \\
\hline Control & 15.4 & 76.9 & 0.20 & 98.7 & 2.22 & 2.7 & 7.1 \\
\hline $\mathrm{ST}+\mathrm{CL}$ & 10.4 & 36.4 & 0.29 & 113.7 & 2.43 & 4.5 & 2.3 \\
\hline$C L$ & 10.6 & 47.0 & 0.23 & 99.6 & 2.27 & 3.0 & 4.7 \\
\hline ST & 12.8 & 54.7 & 0.23 & 93.1 & 2.29 & 2.6 & 5.5 \\
\hline \multicolumn{8}{|l|}{$p$ value } \\
\hline ST & 0.0777 & $<0.0001$ & 0.0002 & $<0.0001$ & 0.0005 & 0.0747 & 0.0075 \\
\hline$C L$ & $<0.0001$ & $<0.0001$ & 0.0007 & $<0.0001$ & 0.0011 & 0.2540 & 0.0004 \\
\hline ST $\times$ CL & 0.1453 & 0.0354 & 0.2582 & 0.0007 & 0.0053 & 0.1803 & 0.5781 \\
\hline LSD & 2.28 & 7.51 & 0.03 & 4.49 & 0.10 & 1.70 & 0.03 \\
\hline \multicolumn{8}{|l|}{2009} \\
\hline Control & 6.3 & 55.8 & 0.11 & 55.5 & 2.04 & 1.1 & 5.1 \\
\hline $\mathrm{ST}+\mathrm{CL}$ & 4.6 & 29.7 & 0.15 & 59.9 & 2.55 & 1.4 & 3.7 \\
\hline $\mathrm{CL}$ & 4.6 & 34.4 & 0.13 & 57.8 & 2.31 & 1.3 & 4.2 \\
\hline ST & 4.3 & 32.9 & 0.13 & 51.6 & 2.47 & 1.2 & 4.0 \\
\hline \multicolumn{8}{|l|}{$p$ value } \\
\hline ST & 0.0254 & $<0.0001$ & 0.0328 & 0.6433 & $<0.0001$ & 0.2687 & 0.0488 \\
\hline$C L$ & 0.1348 & $<0.0001$ & 0.0015 & 0.0053 & $<0.0001$ & 0.0328 & 0.1613 \\
\hline ST $\times$ CL & 0.0214 & 0.0008 & 0.5179 & 0.0668 & 0.0007 & 0.9014 & 0.3545 \\
\hline LSD & 1.47 & 8.54 & 0.02 & 7.36 & 0.14 & 0.30 & 1.32 \\
\hline
\end{tabular}

${ }^{a}$ Control: no shoot thinning and no cluster thinning; ST: shoot thinning (15 primary shoots/m); CL: cluster thinning (distal cluster removed on shoot containing $>2$ clusters). 
Individual cluster weight was increased $20 \mathrm{~g}$ by ST and CL separately (Table 1). The ST*CL interaction was significant with an additive effect for yield per vine, clusters per vine, and berry weight in 2009.

Pruning weights and yields in both years, but particularly in 2009, confirmed the grower reports of high vigor in Corot noir. Pruning weights reported here for 2008 (ranging from 2.6 to $4.5 \mathrm{~kg} / \mathrm{vine}$, or 1.1 to $1.8 \mathrm{~kg} / \mathrm{m}$ canopy) were considerably higher than those reported for other hybrids on nondivided systems in other cool-climate growing regions (Dami et al. 2006, Reynolds et al. 1995, 2004) as well as in New York (Sun et al. 2011). Concord in New York is generally reported to have pruning weights below $\sim 2 \mathrm{~kg} / \mathrm{vine}(0.8 \mathrm{~kg} / \mathrm{m}$ canopy) (Bates 2008, Poni et al. 1994), suggesting that Corot noir, in some instances, may be higher in vigor than Concord. However, hybrids in Arkansas have been reported to have similar vigor to that reported here for Corot noir (Morris et al. 1984, 2004). Vines in all treatments of this study had crop loads that were below the generally accepted range for hybrids (Dami et al. 2006, Reynolds 1989, Reynolds et al. 2004), likely resulting in increased vegetative growth of vines.

ST and CL separately reduced canopy density as reflected by the reduction in OLN and a similar decrease in CEL in 2008. While there were fewer shade-producing contacts in the canopy as well as fewer shading layers between clusters and the nearest canopy boundary, the percentage of photon flux that reached the clusters (CEFA) and leaves (LEFA) did not differ among treatments, suggesting that if changes in canopy density impacted fruit growth and composition, it was not through changes in cluster or leaf light environment. ST and CL had no impact on OLN, CEL, CEFA, or LEFA in 2009 (Table 2). CEL and OLN were generally higher and CEFA and LEFA were lower in 2009 compared to 2008, suggesting a more dense canopy through the fruiting zone despite the fact that pruning weights in 2009 were less than half of those reported for 2008 (Table 1).

Differences between years in yield per vine and pruning weight were striking, with vines in 2009 producing less than half the yield and pruning weight of 2008. A spring frost in May 2009 resulted in loss of $\sim 30 \%$ of primary shoots. Our observations indicated that secondary shoots were extremely fruitful; however, the average cluster weight in 2009 was generally at least $100 \mathrm{~g}$ less than in 2008, and berry number per cluster was also considerably lower. Additionally, yield was likely reduced in 2009 as a result of the excessive vigor of the vines in 2008, resulting in poor floral bud initiation in that year.

Fruit and wine composition. In 2008, soluble solids was increased by 2.5 Brix with CL compared to the control (Table 3 ), but was not affected significantly by ST. However, $\mathrm{pH}$ increased slightly and TA decreased as a result of ST, while CL had no impact on either parameter. In 2009, berry pH and soluble solids were increased by ST and CL, although the increases were low $(<0.8$ Brix compared to the control). TA decreased slightly as a result of ST (Table 3), but was unaffected by CL, a result that has been similarly reported in other hybrid studies investigating CL (Dami et al. 2006,
Morris et al. 1987). Decreases in TA during ripening are due to both $\mathrm{K}^{+} / \mathrm{H}^{+}$exchange and respiration of malic acid (Boulton et al. 1996). Malic acid respiration increases at higher berry temperatures, which can result from greater cluster exposure. However, since the treatments did not alter cluster light environment, greater potassium uptake may be a more plausible explanation for the decrease in TA observed with ST. Greater potassium uptake by vines subjected to ST and/or CL is also the most likely explanation for the increase in $\mathrm{pH}$ observed with both practices. However, the biological relevance of a $\mathrm{pH}$ of 3.53 compared to 3.58 is questionable.

Berry anthocyanin concentration, expressed as malvidin-3glucoside equivalents, ranged from 990 to $1260 \mathrm{mg} / \mathrm{kg}$ berry weight across treatments and years (Table 4). These concentrations are comparable to several of the more intensely pigmented $V$. vinifera cultivars such as Cabernet Sauvignon (Boulton et al. 1996). The concentration of anthocyanins in wines ranged from 670 to $900 \mathrm{mg} / \mathrm{L}$, or a mean of $67 \%$ of the concentration observed in grapes, with a maximum of $86 \%$ observed for the ST + CL treatment. Both of these values are about a factor of 2 greater than typical anthocyanin concentrations (300 to $500 \mathrm{mg} / \mathrm{L})$ and typical extraction efficiency (20 to 50\%) for red wines (Boulton et al. 1996). Anthocyanin extraction efficiency is known to vary among cultivars and sites (Romero-Cascales et al. 2005), although the factors that limit anthocyanin extractability are not well understood. The $\mathrm{pH}$ differential method used here is designed to quantify monomeric anthocyanins, and a possible explanation for our observed results is that the low tannin concentration of the Corot noir wines (described below) resulted in reduced

\begin{tabular}{|c|c|c|c|c|}
\hline \multirow[b]{2}{*}{ Treatment $^{\mathrm{a}}$} & \multicolumn{4}{|c|}{ Canopy variable } \\
\hline & OLN & CEL & CEFA & LEFA \\
\hline \multicolumn{5}{|l|}{2008} \\
\hline Control & 4.75 & 1.39 & 0.17 & 0.31 \\
\hline $\mathrm{ST}+\mathrm{CL}$ & 2.70 & 0.74 & 0.27 & 0.35 \\
\hline$C L$ & 4.37 & 1.24 & 0.23 & 0.33 \\
\hline ST & 3.97 & 1.16 & 0.26 & 0.37 \\
\hline \multicolumn{5}{|l|}{$p$ value } \\
\hline ST & 0.0026 & 0.0100 & 0.0758 & 0.1033 \\
\hline$C L$ & 0.0318 & 0.0414 & 0.3542 & 0.9701 \\
\hline $\mathrm{ST} \times \mathrm{CL}$ & 0.2546 & 0.2538 & 0.4888 & 0.4794 \\
\hline LSD & 1.03 & 0.36 & 0.10 & 0.07 \\
\hline \multicolumn{5}{|l|}{2009} \\
\hline Control & 5.02 & 1.79 & 0.06 & 0.23 \\
\hline $\mathrm{ST}+\mathrm{CL}$ & 5.89 & 2.10 & 0.07 & 0.22 \\
\hline$C L$ & 6.33 & 2.28 & 0.05 & 0.21 \\
\hline ST & 5.79 & 2.02 & 0.11 & 0.23 \\
\hline \multicolumn{5}{|l|}{$p$ value } \\
\hline ST & 0.8935 & 0.8040 & 0.1148 & 0.9869 \\
\hline$C L$ & 0.1390 & 0.3016 & 0.2555 & 0.0856 \\
\hline $\mathrm{ST} \times \mathrm{CL}$ & 0.2274 & 0.5260 & 0.6563 & 0.5242 \\
\hline LSD & 0.96 & 0.55 & 0.07 & 0.03 \\
\hline
\end{tabular}

aControl: no shoot thinning and no cluster thinning; ST: shoot thinning (15 primary shoots $/ \mathrm{m}$ ); CL: cluster thinning (distal cluster removed on shoot containing $>2$ clusters).

'OLN: occlusion layer number; CEL: cluster exposure layer; CEFA: cluster exposure flux availability; LEFA: leaf exposure flux availability. 
polymeric pigment formation and consequently less immediate loss of the anthocyanins. Interestingly, we also observed a significantly higher extraction ratio in 2009 than in 2008 ( $75 \%$ vs. $59 \%, p<0.05$ ), although the reasons for this difference are not obvious, as the same fermentation procedures were followed in both years. No significant difference in berry skin weight (data not shown) or berry weight (Table 1) was observed, so greater adsorption to solids seems unlikely.

Berry skin tannin and seed tannin concentrations ranged from 0.2 to $0.3 \mathrm{mg} / \mathrm{g}$ berry and 0.8 to $1.2 \mathrm{mg} / \mathrm{g}$ berry, respectively, which are comparable to some $V$. vinifera cultivars (Harbertson et al. 2002). Berry skin tannin was not affected

Table 3 Impact of shoot thinning and cluster thinning on berry and wine composition of Corot noir.

Musts were chaptalized prior to fermentation to the same potential alcohol.

\begin{tabular}{|c|c|c|c|c|c|c|}
\hline \multirow[b]{2}{*}{ Treatment $^{\mathrm{a}}$} & \multicolumn{3}{|c|}{ Berry } & \multicolumn{3}{|c|}{ Wine } \\
\hline & $\mathrm{pH}$ & Brix & TA $(g / L)$ & $\mathrm{pH}$ & Alcohol (\% v/v) & TA $(g / L)$ \\
\hline \multicolumn{7}{|l|}{2008} \\
\hline Control & 3.60 & 15.0 & 8.6 & 3.51 & 9.7 & 5.8 \\
\hline $\mathrm{ST}+\mathrm{C}$ & 3.75 & 16.7 & 7.5 & 3.68 & 10.0 & 5.8 \\
\hline$C L$ & 3.71 & 17.5 & 8.0 & 3.60 & 10.1 & 5.8 \\
\hline ST & 3.66 & 16.6 & 7.6 & 3.58 & 9.6 & 5.7 \\
\hline \multicolumn{7}{|l|}{$p$ value } \\
\hline ST & 0.0150 & 0.4924 & 0.0250 & 0.0007 & 0.1462 & 0.3739 \\
\hline $\mathrm{CL}$ & 0.2529 & 0.0289 & 0.2448 & 0.0003 & 0.0034 & 0.3739 \\
\hline $\mathrm{ST} \times \mathrm{CL}$ & 0.9930 & 0.0505 & 0.4867 & 1.0000 & 0.8512 & 0.3739 \\
\hline LSD & 0.10 & 1.68 & 0.76 & 0.03 & 0.20 & 0.25 \\
\hline \multicolumn{7}{|l|}{2009} \\
\hline Control & 3.53 & 15.8 & 11.1 & 3.51 & 8.3 & 6.7 \\
\hline $\mathrm{ST}+\mathrm{C}$ & 3.55 & 16.6 & 10.8 & 3.57 & 9.1 & 6.6 \\
\hline$C L$ & 3.58 & 16.5 & 11.0 & 3.56 & 9.0 & 6.6 \\
\hline ST & 3.55 & 16.6 & 10.5 & 3.58 & 9.0 & 6.6 \\
\hline \multicolumn{7}{|l|}{$p$ value } \\
\hline ST & 0.0381 & 0.0072 & 0.0149 & 0.0008 & 0.0347 & 0.1583 \\
\hline $\mathrm{CL}$ & 0.0002 & 0.0476 & 0.7788 & 0.0008 & 0.0232 & 0.1583 \\
\hline $\mathrm{ST} \times \mathrm{CL}$ & 0.0007 & 0.0649 & 0.2370 & 0.0075 & 0.0534 & 0.1583 \\
\hline LSD & 0.03 & 0.48 & 0.42 & 0.09 & 0.17 & 0.49 \\
\hline
\end{tabular}

aControl: no shoot thinning and no cluster thinning; ST: shoot thinning (15 primary shoots/m); CL: cluster thinning (distal cluster removed on shoot containing $>2$ clusters).

\begin{tabular}{|c|c|c|c|c|c|c|}
\hline Treatment $^{\mathrm{a}}$ & $\begin{array}{c}\text { Berry } \\
\text { anthocyanin } \\
(\mathrm{mg} \mathrm{M-3-G/kg} \\
\text { fresh berry wt) }\end{array}$ & $\begin{array}{c}\text { Wine } \\
\text { anthocyanin } \\
(\mathrm{mg} M-3-G / L))^{b}\end{array}$ & $\begin{array}{l}\text { Berry skin } \\
\text { tannin } \\
\text { (mg/berry } \\
\text { catechin) }\end{array}$ & $\begin{array}{c}\text { Berry seed } \\
\text { tannin } \\
\text { (mg/berry } \\
\text { catechin) }\end{array}$ & $\begin{array}{l}\text { Wine tannin } \\
\text { (mg/L catechin) }\end{array}$ & $\begin{array}{l}\% \text { Tannin } \\
\text { extraction }\end{array}$ \\
\hline \multicolumn{7}{|l|}{2008} \\
\hline Control & 1071 & 671 & 0.28 & 1.18 & 63.6 & 6.3 \\
\hline $\mathrm{ST}+\mathrm{CL}$ & 1260 & 705 & 0.24 & 0.98 & 49.9 & 6.5 \\
\hline$C L$ & 1098 & 700 & 0.27 & 1.06 & 44.0 & 4.9 \\
\hline ST & 1260 & 686 & 0.25 & 0.87 & 48.2 & 6.4 \\
\hline \multicolumn{7}{|l|}{$p$ value } \\
\hline ST & 0.2912 & 0.2928 & 0.3156 & 0.0158 & 0.2511 & \\
\hline$C L$ & 0.9411 & 0.9575 & 0.6798 & 0.9201 & 0.0495 & \\
\hline $\mathrm{ST} \times \mathrm{CL}$ & 0.9394 & 0.3622 & 0.9174 & 0.1166 & 0.0524 & \\
\hline LSD & 499.22 & 80.38 & 0.10 & 0.21 & 30.14 & \\
\hline \multicolumn{7}{|l|}{2009} \\
\hline Control & 994 & 709 & 0.31 & 1.01 & 61.4 & 6.2 \\
\hline $\mathrm{ST}+\mathrm{CL}$ & 1045 & 897 & 0.19 & 0.84 & 42.1 & 6.1 \\
\hline $\mathrm{CL}$ & 1100 & 735 & 0.22 & 1.08 & 53.6 & 6.6 \\
\hline ST & 1147 & 874 & 0.24 & 1.07 & 52.1 & 6.6 \\
\hline \multicolumn{7}{|l|}{$p$ value } \\
\hline ST & 0.6298 & 0.0014 & 0.0819 & 0.5904 & 0.0251 & \\
\hline$C L$ & 0.7985 & 0.3095 & 0.0368 & 0.6436 & 0.0407 & \\
\hline $\mathrm{ST} \times \mathrm{CL}$ & 0.4705 & 0.9485 & 0.5004 & 0.3949 & 0.7229 & \\
\hline LSD & 568.80 & 81.50 & 0.06 & 0.52 & 11.74 & \\
\hline
\end{tabular}

${ }^{a}$ Control: no shoot thinning and no cluster thinning; ST: shoot thinning (15 primary shoots/m); CL: cluster thinning (distal cluster removed on shoot containing $>2$ clusters).

bMalvidin-3-glucose equivalents. 
by ST or CL in 2008, although berry seed tannin was reduced slightly by ST (Table 4). Berry skin tannin was decreased by CL in 2009, but was unaffected by ST; seed tannin was not affected by either practice. Wine tannin was decreased by both ST and CL in 2009, but the concentrations of wine tannin (42 to $64 \mathrm{mg} / \mathrm{L})$ were an order of magnitude below typical concentrations observed in red wines made from $V$. vinifera cultivars (Harbertson et al. 2008). The tannin extractability was very low (6\%) (Table 4) compared to the wine made from $V$. vinifera species (4.9 to 61\%) (Harbertson et al. 2002, Bindon et al. 2010, Adams and Scholz 2008). This finding is consistent with a previous study that reported a tannin extractability of 2 to $4 \%$ for the hybrid cultivar Marechal Foch (Sun et al. 2011). The low tannin extractability may be partly due to low skin tannin concentrations in Corot noir ( 0.2 to $0.3 \mathrm{mg} /$ berry) as compared to $V$. vinifera, as skin tannin appears to be more rapidly and effectively extracted during fermentation (Sampaio et al. 2007). Additionally, insoluble grape cell wall material can bind to tannins and limit its extractability (Bindon et al. 2010). Potentially, the cell wall material of hybrid winegrapes may bind tannins more strongly than in $V$. vinifera, although that would need to be investigated.

ST and/or CL has been reported to improve fruit composition (particularly soluble solids) in the more vigorous hybrid cultivars, at least in some years (Reynolds et al. 1986, Wolpert et al. 1983, Prajitna et al. 2007, Dami et al. 2006). The results of this study were variable with respect to yield components and vine size, but CL increased soluble solids in both years while ST reduced TA (Table 3). CL also reduced wine tannin in both years as indicated by $p$ values compared to the control (Table 4), which could be considered a detrimental impact.

Wine sensory analysis. Panelists were able to detect differences in fruitiness between $\mathrm{ST}+\mathrm{CL}$ and the control from both vintages (Table 5), with the $\mathrm{ST}+\mathrm{CL}$ wines considered more fruity than the control. An additional difference in fruitiness was observed between $\mathrm{ST}+\mathrm{CL}$ and $\mathrm{ST}$ wines in both years and between the CL and control in 2008 (Table 5). Surprisingly, the ST treatment alone was perceived as less fruity than the control in both 2008 and 2009. The results from the sensory analysis were surprisingly consistent across both years, as the growing seasons differed with respect to accumulated GDD from 1 May to 31 Oct (2008 = 1302 GDD base $10^{\circ} \mathrm{C}, 2009=1221 \mathrm{GDD}$; data sourced from the Geneva, NY, weather station maintained by Network for Environment and Weather Applications, www.newa.cornell.edu) as well as yield and pruning weight (Table 1). Precipitation did not vary greatly between years from 1 May to 31 Oct $(2008=519$ $\mathrm{mm}, 2009=549 \mathrm{~mm}$ ), although precipitation from 1 May to 30 June was much higher in $2009(220 \mathrm{~mm})$ compared to the same period in $2008(132 \mathrm{~mm})$. There is no apparent viticultural explanation as to why the ST+CL (and CL wines in 2008) were considered more fruity than the control, or why the ST wines were rated less fruity than the control. A chemical understanding of what controls fruitiness/herbaceousness in Corot noir would facilitate interpretation of the sensory data presented here.
Table 5 Sensory results from two-alternative-forced choice test of Corot noir. The proportion of " 1 more fruity than 2 " is 0.5 by chance, and $p$ values were calculated by chi-squared test (two-tail).

\begin{tabular}{|c|c|c|}
\hline Treatment $^{\mathrm{a}}$ & $\begin{array}{c}\text { Proportion } 1 \\
\text { "more fruity" than } 2\end{array}$ & $p$ value \\
\hline \multicolumn{3}{|l|}{2008} \\
\hline (1-ST+CL/2-Control) & 0.75 & 0.005 \\
\hline (1-CL/2-Control) & 0.75 & 0.005 \\
\hline (1-ST/2-Control) & 0.18 & $<0.001$ \\
\hline$(1-S T+C L / 2-C L)$ & 0.43 & 0.479 \\
\hline (1-ST/2-CL) & 0.5 & 1.000 \\
\hline$(1-\mathrm{ST}+\mathrm{CL} / 2-\mathrm{ST})$ & 0.93 & $<0.001$ \\
\hline \multicolumn{3}{|l|}{2009} \\
\hline (1-ST+CL/2-Control) & 0.75 & 0.005 \\
\hline (1-CL/2-Control) & 0.31 & 0.034 \\
\hline (1-ST/2-Control) & 0.31 & 0.034 \\
\hline$(1-S T+C L / 2-C L)$ & 0.43 & 0.479 \\
\hline (1-ST/2-CL) & 0.5 & 1.000 \\
\hline$(1-S T+C L / 2-S T)$ & 0.88 & $<0.001$ \\
\hline
\end{tabular}

aControl: no shoot thinning and no cluster thinning; ST: shoot thinning (15 primary shoots $/ \mathrm{m}$ ); CL: cluster thinning (distal cluster removed on shoot containing $>2$ clusters).

Cost of implementing practices. A simple accounting analysis of the costs of implementing CL and ST was performed in order to depict a realistic financial scenario for commercial Corot noir growers of the potential costs and benefits of adopting these practices. Variable production costs of growing winegrapes in the New York Finger Lakes region were estimated based on a published report of $V$. vinifera production (White 2008). The two primary costs associated with implementing ST and/or CL are (1) additional vineyard labor hours required to complete the thinning in consort with other ongoing field practices and (2) potential opportunity cost if total yield is decreased as a result of either practice and thus there are fewer grapes to sell and/or make into wine. It is likely that the cost of labor estimates used in our analysis that were determined for $V$. vinifera (White 2008) are lower than would be required for hybrids due to the generally larger canopy size of hybrids; therefore, required prices to compensate for labor costs may be higher than reported here. If a grower has to spend money to implement cluster and/or ST, and then has fewer grapes to sell at the standard industry price, then the grower can expect to receive lower total revenue for their crop. Logically, if a grower expects to maintain the same level of welfare (total revenue) following implementation of ST and/or CL, the price they charge for Corot noir grapes would need to be above market price.

In 2008 and 2009 the average prices for Corot noir grapes in the Finger Lakes were $\$ 570$ and $\$ 503$ per tonne, respectively (Walter-Peterson 2008, 2009). The price per tonne of Corot noir grapes in 2008 that a grower would need to charge in order to maintain constant welfare would increase from a base market price of $\$ 570$ per tonne for the control up to $\$ 865$ per tonne for the ST+CL vineyard (Table 6). For the same parameters in 2009 , the price per tonne to maintain constant grower welfare would need to increase from $\$ 503$ 
Impact of Shoot and Cluster Thinning on Corot noir - 55

\begin{tabular}{|c|c|c|c|c|c|c|}
\hline Treatment $^{\mathrm{a}}$ & $\begin{array}{c}\begin{array}{c}\text { Additional } \\
\text { production } \\
\text { cost/ha }\end{array} \\
\end{array}$ & $\begin{array}{l}\text { Additional } \\
\text { production } \\
\text { cost/tonne }\end{array}$ & $\begin{array}{c}\text { Yield } \\
\text { tonnes/ha }\end{array}$ & $\begin{array}{c}\text { Expected } \\
\text { revenue/ha }\end{array}$ & $\begin{array}{c}\text { Preferred price/ } \\
\text { tonne to } \\
\text { maintain welfare }\end{array}$ & $\begin{array}{l}\text { Additional } \\
\text { cost/bottle }\end{array}$ \\
\hline \multicolumn{7}{|l|}{2008} \\
\hline Control & $\$ 0$ & $\$ 0$ & 23.3 & $\$ 13,279$ & $\$ 570$ & $\$ 0.00$ \\
\hline $\mathrm{ST}+\mathrm{CL}$ & $\$ 287^{e}$ & $\$ 18$ & 15.7 & $\$ 8,938$ & $\$ 865$ & $\$ 0.41$ \\
\hline$C L$ & $\$ 153^{f}$ & $\$ 9$ & 17.9 & $\$ 10,215$ & $\$ 749$ & $\$ 0.25$ \\
\hline ST & $\$ 133^{9}$ & $\$ 6$ & 21.1 & $\$ 12,002$ & $\$ 637$ & $\$ 0.09$ \\
\hline \multicolumn{7}{|l|}{2009} \\
\hline Control & $\$ 0$ & $\$ 0$ & 9.6 & $\$ 4,844$ & $\$ 503$ & $\$ 0.00$ \\
\hline $\mathrm{ST}+\mathrm{CL}$ & $\$ 287$ & $\$ 41$ & 7.0 & $\$ 3,492$ & $\$ 738$ & $\$ 0.33$ \\
\hline $\mathrm{CL}$ & $\$ 153$ & $\$ 16$ & 9.6 & $\$ 4,844$ & $\$ 518$ & $\$ 0.02$ \\
\hline ST & $\$ 133$ & $\$ 17$ & 8.1 & $\$ 4,055$ & $\$ 616$ & $\$ 0.16$ \\
\hline
\end{tabular}

aControl: no shoot thinning and no cluster thinning; ST: shoot thinning (15 primary shoots/m); CL: cluster thinning (distal cluster removed on shoot containing $>2$ clusters).

${ }^{b}$ Expected revenue a commercial grower can expect to receive for Corot noir calculated by multiplying yield (tonnes) by the reported average industry price for Corot noir (2008 $=\$ 570 /$ tonne, $2009=\$ 503 /$ tonne).

'Price per tonne of Corot noir that a commercial grower would need to charge to compensate for the two main costs associated with implementing thinning practices: reduced grape yield and additional production costs.

${ }^{d}$ Additional cost per bottle produced after implementing thinning practices, if the commercial grower retains grapes to make wine instead of selling them at market price. Assumes $491.4 \mathrm{~L}$ wine (or 655.2 bottles) per tonne of grapes.

${ }^{e}$ Additional production cost per hectare for ST and CL in V. vinifera, estimated from White (2008).

${ }^{\dagger}$ Additional production cost per hectare for $C L$ in $V$. vinifera (White 2008).

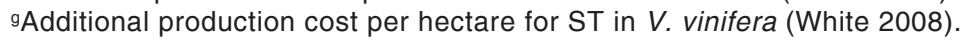

to $\$ 738$ per tonne. The variability in these prices reflects the specific practices implemented (Table 6). The increase in price per $750 \mathrm{~mL}$ bottle required to compensate for the higher fruit costs plus additional vineyard labor ranged from $\$ 0.09$ to $\$ 0.41$ in 2008 and from $\$ 0.02$ to 0.32 in 2009 . It is unclear whether hybrid fruit growers who implement ST and/ or CL could recapture their costs by charging substantially higher market prices or whether grape buyers would be willing to pay such a premium without compelling enhancements to fruit quality or flavor. However, the sensory analysis results in this study indicate a consistent increase in fruitiness with CL (alone in 2008 or combined with ST in both years), a characteristic positively associated with consumer preference (Bogart and Bisson 2006). Wine consumers may be willing to pay more for such wines or may be more likely to purchase the wine again. Ultimately, a hybrid grapegrower's decision of whether to implement thinning practices is best determined based on a rational analysis of the potential costs and benefits similar to the one presented here.

\section{Conclusion}

The Corot noir vines used in this study were extremely vigorous, with high pruning weights and low crop loads. While the impact of ST on yield and yield components varied in the two years of this study, ST was consistent in reducing both cropload and TA in both years. CL also demonstrated a variable impact on yield and yield components, but improved soluble solids in both years. Increasing retained node numbers during dormant pruning may have more successfully improved fruit composition by reducing overall vine vigor. Surprisingly, the impact of ST and CL on the wine sensory analysis was consistent: in both years of the study, the panelists reported that the ST+CL wine was perceived as more fruity than the control and that the $\mathrm{ST}+\mathrm{CL}$ wine was perceived as more fruity than the ST only wine. Poor tannin extraction from Corot noir was observed, which is consistent with previous work on Marechal Foch, and could potentially be the result of binding between cell wall material and tannins. If that occurs, it would compromise the effectiveness of exogenous tannin additions to hybrid red wine fermentations, as is sometimes practiced commercially. Further investigation into the poor tannin extraction from hybrids is warranted. Lastly, implementing CL and/or ST would require a hybrid grapegrower to charge considerably higher prices for their grapes to compensate for the lost yields and additional production costs. It is uncertain whether the quality or flavor enhancements to Corot noir fruit as a result of CL and/or ST would warrant such price increases under existing hybrid winegrape market conditions.

\section{Literature Cited}

Adams, D.O., and R.C. Scholz. 2008. Tannins-the problem of extraction. In Proceedings of the Thirteenth Australian Wine Industry Technical Conference. R. Blair et al. (eds.), pp. 160-164. AWITC, Glen Osmond, South Australia.

Bates, T. 2008. Pruning level affects growth and yield of New York Concord on two training systems. Am. J. Enol. Vitic. 59:276-286.

Bindon, K.A., P.A. Smith, and J.A. Kennedy. 2010. Interaction between grape-derived proanthocyanidins and cell wall material. 1. Effect on proanthocyanidin composition and molecular mass. J. Agric. Food Chem. 58:2520-2528.

Bogart, K., and L. Bisson. 2006. Persistence of vegetal characters in winegrapes and wine. Prac. Winery Vineyard 26:13-20.

Boulton, R.B., V.L. Singleton, L.F. Bisson, and R.E. Kunkee. 1996. Principles and Practice of Winemaking. Chapman \& Hall, New York.

Cahoon, G.A., and G.R. Nonnecke. 1982. Cluster and shoot thinning as a commercial cultural practice. In Proceedings of the Ohio Grape-Wine Short Course, pp. 65-70. Ohio Agricultural Research and Development Center, Wooster. 
Dami, I., D. Ferree, A. Prajitna, and D. Scurlock. 2006. A five-year study on the effect of cluster thinning on yield and fruit composition of 'Chambourcin' grapevines. HortScience 41:586-588.

Fisher, K.H., O.A. Bradt, J. Wiebe, and V.A. Dirks. 1977. Clusterthinning 'De Chaunac' French hybrid grapes improves vine vigor and fruit quality in Ontario. J. Am. Soc. Hortic. Sci. 102:162-165.

Harbertson, J.F., J.A. Kennedy, and D.O. Adams. 2002. Tannins in skins and seeds of Cabernet Sauvignon, Syrah, and Pinot noir berries during ripening. Am. J. Enol. Vitic. 53:54-59.

Harbertson, J.F., E.A. Picciotto, and D.O. Adams. 2003. Measurement of polymeric pigments in grape berry extracts and wines using a protein precipitation assay combined with bisulfite bleaching. Am. J. Enol. Vitic. 54:301-306.

Harbertson, J.F., R.E. Hodgins, L.N. Thurston, L.J. Schaffer, M.S. Reid, J.L. Landon, C.F. Ross, and D.O. Adams. 2008. Variability of tannin concentration of red wines. Am. J. Enol. Vitic. 59:210-214.

Howell, G.S., T.K. Mansfield, and J.A. Wolpert. 1987. Influence of training system, pruning severity, and thinning on yield, vine size, and fruit quality of Vidal blanc grapevines. Am. J. Enol. Vitic. $38: 105-112$

Lawless, H.T., and H. Heymann. 2010. Sensory Evaluation of Food: Principles and Practices. 2d ed. Springer Publishing, New York.

Looney, N.E. 1981. Some growth regulator and cluster thinning effects on berry set and size, berry quality, and annual productivity of de Chaunac grapes. Vitis 20:22-25.

Meyers, J.M., and J.E. Vanden Heuvel. 2008. Enhancing the precision and spatial acuity of point quadrat analyses via calibrated exposure mapping. Am. J. Enol. Vitic. 59:425-431.

Morris, J.R., C.A. Sims, J.E. Bourque, and J.L. Oakes. 1984. Influence of training system, pruning severity, and spur length on yield and quality of six French-American hybrid grape cultivars. Am. J. Enol. Vitic. 35:23-27.

Morris, J.R., C.A. Sims, R.K. Striegler, S.D. Cackler and R.A. Donley. 1987. Effects of cultivar, maturity, cluster thinning, and excessive potassium fertilization on yield and quality of Arkansas wine grapes. Am. J. Enol. Vitic. 38:260-264.

Morris, J.R., G.L. Main, and O.L. Oswald. 2004. Flower cluster and shoot thinning for crop control in French-American hybrid grapes. Am. J. Enol. Vitic. 55:423-426.

Mullins, M.G., A. Bouquet, and L.E. Williams. 1992. Biology of the Grapevine. Cambridge University Press, Cambridge, UK.

Poni, S., A.N. Lakso, J.R. Turner, and R.E. Melious. 1994. Interactions of crop level and late season water stress on growth and physiology of field-grown Concord grapevines. Am. J. Enol. Vitic. 45:252-258.

Pool, R.M., C. Pratt, and H.D. Hubbard. 1978. Structure of base buds in relation to yield of grapes. Am. J. Enol. Vitic. 29:36-41.
Prajitna, A., I.E. Dami, T.E. Steiner, D.C. Ferree, J.C. Scheerens, and S.J. Schwartz. 2007. Influence of cluster thinning on phenolic composition, resveratrol, and antioxidant capacity in Chambourcin wine. Am. J. Enol. Vitic. 58:346-350.

Preszler, T., T.M. Schmit, and J.E. Vanden Heuvel. 2010. A model to establish economically sustainable cluster-thinning practices. Am. J. Enol. Vitic. 61:140-146.

Reisch, B.I., R.S. Luce, B. Bordelon, and T. Henick-Kling. 2006. 'Corot noir' grape. Bulletin 159. New York State Agricultural Experiment Station, Geneva.

Reynolds, A.G. 1989. Impact of pruning strategy, cluster thinning, and shoot removal on growth, yield, and fruit composition of low-vigor De Chaunac vines. Can. J. Plant Sci. 69:269-275.

Reynolds, A.G., D.A. Wardle, and A.P. Naylor. 1995. Impact of training system and vine spacing on vine performance and berry composition of Chancellor. Am. J. Enol. Vitic. 46:88-97.

Reynolds, A.G., R.M. Pool, and L.R. Mattick. 1986. Effect of shoot density and crop control on growth, yield, fruit composition, and wine quality of 'Seyval blanc'. J. Am. Soc. Hortic. Sci. 111:55-63.

Reynolds, A.G., D.A. Wardle, M.A. Cliff, and M. King. 2004. Impact of training system and vine spacing on vine performance, berry composition, and wine sensory attributes of Seyval and Chancellor. Am. J. Enol. Vitic. 55:84-95.

Romero-Cascales, I., A. Ortega-Regules, J.M. López-Roca, J.I. Fernández-Fernández, and E. Gómez-Plaza. 2005. Differences in anthocyanin extractability from grapes to wines according to variety. Am. J. Enol. Vitic. 56:212-219.

Sampaio, T.L., J.A. Kennedy, and M.C. Vasconcelos. 2007. Use of microscale fermentations in grape and wine research. Am. J. Enol. Vitic. 58:534-539.

Sun, Q., G. Sacks, S. Lerch, and J.E. Vanden Heuvel. 2011. Impact of shoot thinning and harvest date on yield components, fruit composition, and wine quality of Marechal Foch. Am. J. Enol. Vitic. 62:32-41.

Walter-Peterson, H. 2008. 2008 harvest price list for grapes. Finger Lakes Vineyard Notes. 6:2-3. Cornell Cooperative Extension, Penn Yan, NY

Walter-Peterson, H. 2009. 2009 Finger Lakes grape price list. Finger Lakes Vineyard Notes. 5:1-4. Cornell Cooperative Extension, Penn Yan, NY

White, G.B. 2008. Costs of establishment and production of vinifera grapes in the Finger Lakes region of New York-2007. Publication E.B. 2008-05. Cornell University, Ithaca, NY.

Wolpert, J.A., G.S. Howell, and T.K. Mansfield. 1983. Sampling Vidal Blanc grapes. 1. Effect of training system, pruning severity, shoot exposure, shoot origin, and cluster thinning on cluster weight and fruit quality. Am. J. Enol. Vitic. 34:72-76. 